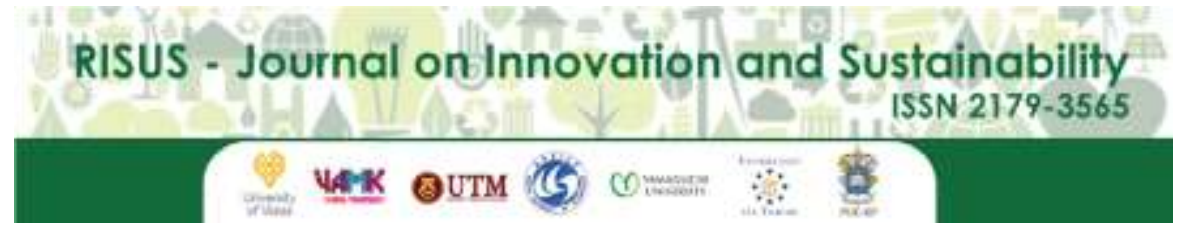

RISUS - Journal on Innovation and Sustainability volume 10, número 3 - 2019

ISSN: $2179-3565$

Editor Científico: Arnoldo José de Hoyos Guevara Editor Assistente: Luciano da Silva Ferreira Leite Avaliação: Melhores práticas editoriais da ANPAD

\title{
CO-DESIGN OF SERVICE INNOVATION THROUGH PROBLEM BASED LEARNING IN HIGHER EDUCATION INCORPORATING LIVING LABS
}

\author{
Co-projeto de inovação de serviço através de aprendizagem baseada em problemas no ensino superior \\ incorporando labs vivos
}

\begin{abstract}
Sadayo Hirata
Graduate School of Engineering Management, Shibaura Institute of Technology, Tokyo, Japan, 1085048 (E-mail: hirata-s@shibaura-it.ac.jp)
\end{abstract}

\begin{abstract}
The aim of this research is to propose a model of problem based learning to develop service innovators. This model futures empirical finding for problem solving by implementing with enterprises and higher education institutions. This study focuses on craftsmanship in the manufacturing small enterprises in Japan. It is because the management of a small enterprise is tight and it is difficult to demonstrate the value of excellent craftsmanship. This study shows a model of co-design of service innovation and the execution process of the model by enterprises and higher education institutions incorporating living labs which is one methodology to practice open innovation.
\end{abstract}

Key words: Human resource development; Living labs; Manufacturing; Production service; Service innovation; SME 
RISUS - Journal on Innovation and SUstainability ISSN 2179-3565
C)

\section{(15SN2179-3565}

Wex

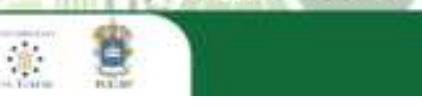

RISUS - Journal on Innovation and Sustainability volume 10, número 3 - 2019

ISSN: 2179-3565

Editor Científico: Arnoldo José de Hoyos Guevara Editor Assistente: Luciano da Silva Ferreira Leite Avaliação: Melhores práticas editoriais da ANPAD

\section{CO-PROJETO DE INOVAÇÃO DE SERVIÇO ATRAVÉS DE APRENDIZAGEM BASEADA EM PROBLEMAS NO ENSINO SUPERIOR INCORPORANDO LABS VIVOS}

Co-design of service innovation through problem based learning in higher education incorporating living labs

\section{Sadayo Hirata}

Graduate School of Engineering Management, Shibaura Institute of Technology, Tokyo, Japan, 1085048 (E-mail: hirata-s@shibaura-it.ac.jp)

RESUMO: Esta pesquisa tem como objetivo identificar a tendência da tecnologia e o surgimento de tempo do design dominante da impressora a jato de tinta e da máquina $\mathrm{NC}$ usando o termo $\mathrm{F}$ na patente japonesa. $\mathrm{O}$ termo F foi empregado em vez da Classificação Internacional de Patentes (IPC) por causa do ponto de vista múltiplo do tema e fornece uma certa área técnica. O tempo de entrada do produto no mercado foi avaliado pela curva $S$ do ciclo de vida do produto e o ciclo de vida da tecnologia também foi investigado.

Palavras-chave: Design dominante; Ciclo de vida do produto; Patente japonesa; Termo F

\section{ACEITO EM: 20/10/2019}




\section{Introduction}

There are lots of small and medium enterprises (SMEs) in Japan. Despite its small scale, SMEs are supporting the Japanese economy. As shown in figure 1, in Japan, 99.7\% of the enterprises are SMEs (Ministry of Economy, Trade and Industry in Japan, Small and medium enterprise agency, 2014). In terms of the number of enterprises, SMEs are overwhelmingly larger than large enterprises. In terms of the number of employees, SMEs are also lager.

SMEs are largely involved in subcontracted manufacturing which is the backbone of a number of principal industries of Japan, such as the automobile industry. Therefore, SMEs accumulate potential technologies and skills in order to meet the strict demands of large enterprises (Ministry of economy, Trade and industry, Labor and welfare editing in Japan, 2016).

However, the management of SMEs are tight and SMEs are lack the core personnel to lead research and development in addition to manufacturing. It is difficult for SMEs alone to demonstrate its value. Therefore, discovering superior craftsmanship and translating it into earning power is a problem that requires urgent attention (Small and medium enterprise agency in Japan, 2015).

\section{Aim and Method of This Study}

The aim of this research is to propose a model of problem based learning to develop service innovators. Both of enterprises and higher education institution future empirical finding for problem solving by implementing this model.

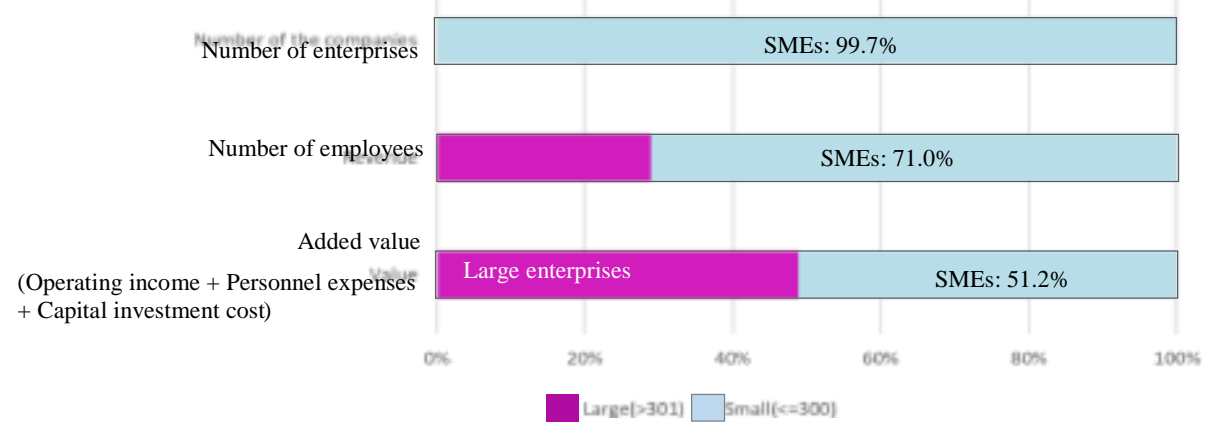

Figure 1 Ratio of Manufacturing Enterprises in Japan

In this research, participation observation (J. Blomberg, M. Burrell, and G. Guest, 2002) and interview were used for data collection. In addition, co-design (J. Blomberg, M. Burrell, and G. Guest, 2002) and living labs (European Network of Living Labs, 2018, F. Akasaka, A. Kimura, 2017) were used for analysis and problem solving. Co-design is is one methodology for value creation and an approach to involve various stakeholders and work together to solve problems. Living lab is one methodology of open innovation and an approach to understand and solve problems at workplace and society's site.

This study shows a model of co-design of service innovation and the execution process of the model by enterprises and higher education institutions incorporating living labs which is one methodology to practice open innovation. This model futures empirical finding for problem solving by implementing with enterprises and higher education institutions.

\section{Issues to be Solved}

\subsection{Lack of human resources capable of management leading to service innovation}

Japanese government advocate strengthening of power to make profits by not only reforming by traditional cost reduction and time reduction, but also by improving productivity and value creation, in order to realize differentiation by high quality and high added value (Baines T.S., et al., 2009). 
Meanwhile, manufacturing companies in Japan have accumulated techniques and experiences of manufacturing, but it can not be said that they are fully working on intangible value creation and grasping customer satisfaction. That is Japanese manufacturing companies are not good at service innovation yet.

Consequently, management reforms that cause service innovations are necessary for manufacturing industry. Due to the spread of design thinking, the idea creation method which is possible to be applied to manufacturing has become known (). However, many enterprises haven't learned such service innovation that had not mentioned in the past education of engineers. In Japan, the definition of service is not clearly recognized yet (T. Arai, Y. Shimomura, T. Hara, 2007). Even the academic conference in Japan only presented reference standards for servisology. Therefore, the manufacturing enterprises need to learn about value creation again (R. F. Lusch, S. L. Vargo, 2014).

\subsection{Lack of educational opportunities in SMEs}

99\% of all Japanese companies are SMEs. Many of which are engaged in contract manufacturing from large companies. As in Europe and the United States, small and medium enterprises need to complement innovation knowledge to enhance their profitability centered on their own specialty, in order to independently trade with overseas markets as well as large enterprises.

Large enterprises can learn through OJT (On the Job Training) in departments such as in-house education, study abroad, research and development, marketing, etc. On the other hand, small enterprises with limited management resources do not have much opportunity to learn again like large enterprises do. However, because it is small and medium scale, there is a possibility that the educational effect will be penetrated and practiced quickly.

3.3 Lack of higher education to help to solve problems of enterprises in the traditional curriculum Traditionally, universities have built a curriculum centered on subjects in accordance with educational policy. Meanwhile, the environment surrounding enterprises and companies is rapidly changing. As mentioned in 2.1 and 2.2, in recent years, there has been a strong demand for value creation by service innovation to make the manufacturing industry survive.

However, higher education to solve new problems in the industry was not found in the traditional curriculum that teaching industrial technology. There is concern about the gap between the traditional curriculum and higher education necessary for enterprises. The higher education is required to design provide new problem-solving education. Therefore, the universities need to understand concretely what kinds of problems the enterprises suffer from before the preparation of the new problem-solving education.

\section{Survey of Problems of Manufacturing SMEs}

\subsection{Overview of the survey}

As shown in Table 1, this survey was conducted between 2015 and 2017 to understand the problems that manufacturing SMEs have.

The subjects to be investigated were four manufacturing SMEs ranging in size from tens to 100 employees. This survey was conducted by the enterprises, six students and one faculty member in cooperation. The participated observation and interview were used for the survey methods.

The participated observation was focused on the servitization.of manufacturing industry. It is the servitization.that how far each enterprise's service innovation was progressing.

We focused on management problems and ingenuity to solve problems by management and employees through living labs. 
Table 1 Overview of Survey

\begin{tabular}{ccccc}
\hline \multirow{2}{*}{ Enterprise } & Production type & \multicolumn{3}{c}{ Investigation (hour) } \\
\cline { 3 - 5 } & & Observation & Interview & Total \\
\hline A & Metal processing & 3.5 & 2.5 & 6 \\
\hline B & Metal processing & 3 & 3 & 6 \\
\hline C & Electronic parts & 4 & 3 & 7 \\
\hline D & Motor & 5 & 1.5 & 6.5 \\
\hline
\end{tabular}

\subsection{The results of the survey}

\subsubsection{Progress of servitization}

As a result of the survey shown in 3.1, the following information was revealed.

In participated observation, we understood the difference of servitization among the enterprises. The progress of manufacturing servitization of each enterprise was classified based on the four steps of the industrial revolution, -Mechanization, water power, steam power,\| - Assembly line, electricity,॥ - Computer and automation,\| and -Cyber-physical systems\|. A summary of the results about servitization of each enterprise is shown in Table 2.

Table 2 A Summary of the Results about Servitization

\begin{tabular}{|c|c|c|c|c|c|}
\hline Enterprise & Production Type & $\begin{array}{l}\text { Mechanization, } \\
\text { water power, } \\
\text { steam power }\end{array}$ & $\begin{array}{l}\text { Assembly line, } \\
\text { electricity }\end{array}$ & $\begin{array}{l}\text { Computer and } \\
\text { automation }\end{array}$ & $\begin{array}{l}\text { Cyber-physical } \\
\text { systems }\end{array}$ \\
\hline $\mathbf{A}$ & Metal processing & & & & \\
\hline B & Metal processing & & & & \\
\hline $\mathrm{C}$ & Electronic parts & & & & \\
\hline D & Motor & & & & $\longrightarrow$ \\
\hline
\end{tabular}

In the interview, several common terms and differences were extracted about management problems about management problems and ingenuity to solve problems. A summary of the survey results is shown in Table 3.

4.2.2 Comparison of management problems and ingenuity to solve problems

All of the four enterprises were in common in that they were also engaged in multi-product small-volume production that was difficult to set up a production line, but also challenge the prototyping of new products and new services using the excellent technology.

In particular, several characteristics were clarified in the homepage and leaflet brochure. All of the enterprises listed their core technologies. Furthermore, enterprise C and D were appealing the value of their technologies to customers for the usage by customers.

Table 3 A Summary of the Results about Management Problems and Ingenuity to Solve Problems

\begin{tabular}{l|l|l|l|c|c}
\hline \multirow{2}{*}{ No. } & Management Problems and Ingenuity to Solve Problems & \multicolumn{3}{|c}{ Servitization } \\
\cline { 3 - 5 } & & \multicolumn{2}{|c|}{ Delayed } & \multicolumn{2}{|c}{ Leading } \\
\cline { 3 - 5 } & A & B & C & D \\
\hline
\end{tabular}




\begin{tabular}{|c|c|c|c|c|c|}
\hline 1 & $\begin{array}{l}\text { Multi-product Small-volume Production which is difficult to set up } \\
\text { production line }\end{array}$ & Y & Y & Y & Y \\
\hline 2 & Utilize production management tool & $\mathrm{Y}$ & Y & Y & Y \\
\hline 3 & Creation of the prototype of new product / service with good skill & $\mathrm{Y}$ & Y & Y & Y \\
\hline 4 & Presentation of their superior technology through the website etc. & $\mathrm{Y}$ & Y & Y & Y \\
\hline 5 & $\begin{array}{l}\text { Accountability of value of superior technology giving to customers } \\
\text { through the website etc. }\end{array}$ & Not yet & Not yet & Y & Y \\
\hline 6 & Adjustment to increase orders to take use of their excellent & & & Y & Y \\
\hline 7 & $\begin{array}{l}\text { Pricing including the value of their excellent technology for } \\
\text { customers }\end{array}$ & Not yet & Not yet & Y & Y \\
\hline 8 & Pioneering new customers at overseas exhibitions & Not yet & Not yet & Y & Y \\
\hline & & Not yet & Not yet & & \\
\hline
\end{tabular}

According to participated observation and interview, enterprise $\mathrm{C}$ and $\mathrm{D}$ calculated prices from added value and negotiated with customers rather than accumulating costs. Enterprise C and D were implementing selection of orders to take advantage of core technologies. Although competition in the market was severe, enterprise C and D seemed to have accumulated experience of explanation their excellent technologies to customers.

On the other hand, enterprise A and B had habitually accepted prices proposed by large companies. Enterprise A and B were always waiting for any order by large companies and had never refused any order. Although enterprise A and B were able to maintain relations with certain large companies, they received few orders using their excellent technologies.

\subsubsection{Higher education required by enterprises}

These survey results were shared with four companies and discussed. As a result, the following view was obtained.

- Even without the assemble line for mass production which the large companies in the manufacturing industry are all working on, service development can be promoted while using strengths.

- It is difficult to create value simply by having excellent technologies .

- Explanation of value for customers is necessary for both price negotiation and market competition.

- Compared with mass production, multi-product small-volume production can provide various values, but the explanation of the value is diverse and difficult.

- Regarding improvement of technology, the method of training in-house training is mature, but training in-house for improvement of the explanation of value is not easy.

Ultimately, we conclude that improving the capability of the explanation about the value that the excellence of technologies brings to customers is the top priority.

Therefore, enterprise A, students and the faculty member cooperated and tried to visualize core technology of enterprise A based on living labs methodology at their workplace in enterprise A (S. Hirata, 2016).

\section{A Case of Problem Based Learning in SMEs through Industry-Academia Collaboration}

5.1 The extraction of visualization of core technology through participant observation of enterprise An excerpt from the visualization of the core technology through living labs methodology at the workplace of enterprise $\mathrm{A}$ is shown below.

Time was spent with the craftsmen at their factory and office in order to gain a practical understanding of the efforts required and ingenious devices implemented in the individual processes of metal casting through participant observation (Y. Yamaguchi, S. Odajima, S. Hirata, 2016). We carefully observed the work of the craftsmen's usual work and recorded what we understood. For instance, the extent of contraction, expansion, and bending differs depending on the thickness and shape of the metal to be poured later. Therefore, the dimensions 
of a wood model to make the mold must be determined in advance in order to control for such a complicated variable. The design of a part to be larger or smaller depends on tacit knowledge gained from the experience of each craftsman.

A variety of polishing tools with varying widths have been fabricated by individuals at their own personal expense in order to create complex surfaces. Standardizing or formulating manuals for such gut feelings and experience is difficult, and these skills must be acquired through on-the-job training by repeatedly forging alongside an expert. Since there is a limit to how much the gut feelings and experience of an expert can convey, creating memos for items of consideration and operations and making them available for search by ICT is believed to be effective.

\subsection{Solutions for problem solving by so-design}

The result of the participant observations in 4.1 were recorded in notes, pictures and videos as Table 4. Based on these data, we conducted co-design to develop a system that explains the superior technology among enterprise A, students and the faculty member.

As a result of the co-design, by registering the above data in the database and reading the ID of each work tool with a sensor, the explanation of the technology related to each tool could be displayed from the personal computers by text, photo and video. Proposal was made to use this system for training human resources and negotiating with customers in order to account the excellent technologies.

Table 4 Extraction of Superior Technology and Classification of its Accounting Method

Classification of its Accounting Method

\begin{tabular}{lcccccc}
\cline { 2 - 4 } & Possibility of & & & & \\
Application of & Documen & Phot & Vide & OJT \\
Automation to & ts & o & o & \\
Replace Humans & & & & \\
with Machines & & & & \\
\hline
\end{tabular}

(1) Capable of determining the dimensions of patterns and anticipating shrinkage allowance and warpage of finished model.

-Computer-aided design(CAD)/

Computer-aided

(2) Capable of increasing the purity of metal to be manufacturing(CAM casted by adding a groove and inflection to the mold for precipitation and flotation of impurities.

(3) Capable of adding a projection that enables product to be taken out without breaking the mold upon dismantling.

)

-Three-dimensional

(3D) data

Sensor
-Vibration controller]

-Power assist

Traceability

hrough business model

(13) Capable of controlling quality standards for management each client.

NG NG NG Best

$\begin{array}{cccc}\text { Best } & \text { Goo } & \text { Goo } \\ & \mathrm{d} & \text { NG } & \mathrm{d}\end{array}$

Good Best NG $\begin{gathered}\text { Goo } \\ \mathrm{d}\end{gathered}$

\begin{tabular}{ccc}
$:$ & $:$ & $:$ \\
\hline & & Goo
\end{tabular}

Legends for judgment standard: $\quad$ Best: optimal as an option, Good: can be an option, NG: inappropriate for an option

\section{Conclusion}

Based on this empirical study, a model of problem based learning for higher education through industryacademia collaboration was indicated as shown in figure 2. In addition, the process of practicing this model through living labs, in cooperation with enterprises and higher education institutions was shown.

Application of this model to higher education institutions and enterprises would support sustainable development of human resources who lead service innovation. This model can be applied not only to SMEs but also to large companies. 


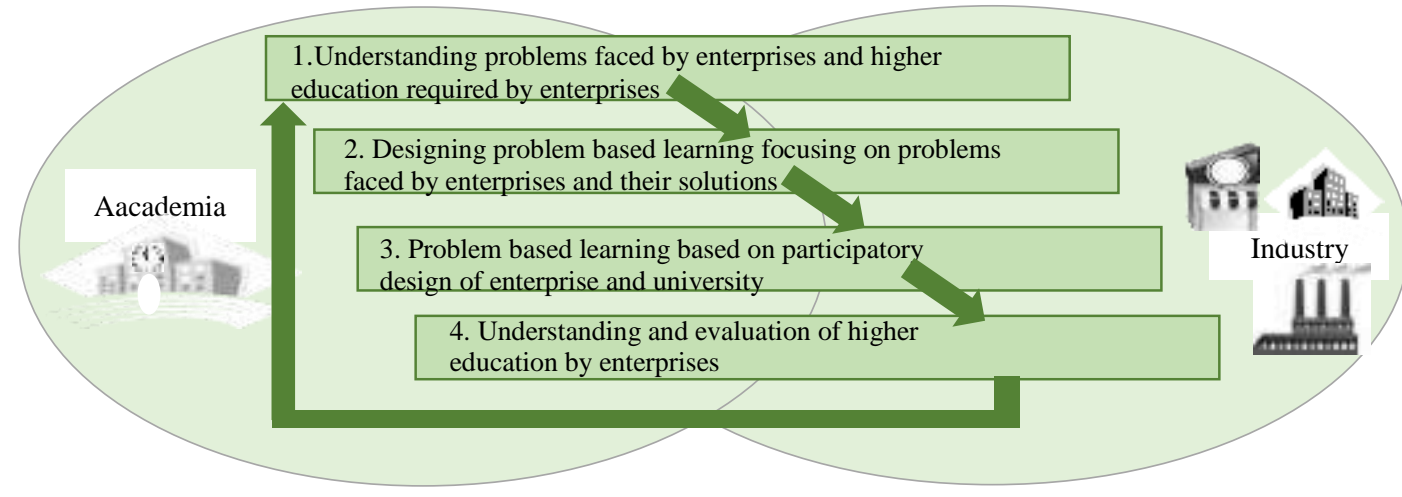

Figure 2 A Model of Problem Based Learning of Higher Education through Academia-Industry Collaboration

\section{References}

[1] Baines T.S., et al., The Servitization of Manufacturing: A Review of Literature [J]. Journal of Manufacturing Technology Management, 2009,20(5),547-567

[2] F. Akassaka, A. Kimura, Analyzing Methodological Features of Living Labs - Case study of Living Lab Practice in Japan [C]. Bulletin of JSSD, 2017, 22-23 (In Japanese)

[3] G. Pahl, W. Beitz, Engineering Design - a systematic approach, Springer, Berlin [M]. 1996

[4] Ministry of Economy, Trade and Industry in Japan, SMEs Agency, White Paper on Japanese SMEs [R]. 2014

[5] Ministry of economy, Trade and Industry, Labor and Welfare editing, White Paper on Japanese Manufacturing [R]. Tokyo: Economic industry research committee, 2016 (In Japanese)

[6] J. Blomberg et al., Ethnographic Field Methods and Their Relation to Design [J]. Participatory Design: Principles and Practices, Ed. Douglas Schuler, Erlbaum Associates, 1993,123-155

[7] J. Blomberg, M. Burrell, and G. Guest, An ethnographic approach to design, In the human-computer interaction handbook [M]. Julie A. Jacko and Andrew Sears (eds.), L. Erlbaum Associates Inc., NJ, USA, 2002,964-986

[8] R. F. Lusch, S. L. Vargo, Service Dominant Logic [M]. Cambridge University Press, 2014

[9] Small and medium enterprise agency in Japan, Basic Survey on the Direction of Advancement of Casting Technology for Strengthening Government bond Competitiveness of Important Industries in Japan [R], 2015 (in Japanese)

[11] S. Hirata, Study on Manufacturing Services by IoT of Japanese SMEs: Co-design of IoT for High-mix Low-Volume Production [C]. in Proc. 57th Conf. Japan Management System Association National Research Presentation Competition, Sapporo University, Hokkaido, Japan, 2016,30-33 (In Japanese)

[12] T. Arai, Y. Shimomura, T. Hara, Development of Service CAD System based on Service Engineering (38 ${ }^{\text {th }}$ report $)-$ New Understanding on Difference between Service and Products [C]. in Proc. 38th Conf. of Precision Engineering Society, Spring Competition, 2007,945-946 (In Japanese)

[13] Y. Yamaguchi, S. Odajima, S. Hirata, Value Creation and Productivity Improvement by Succession of Skills Training of Service Management Leaders by Ethnography and ICT [C]. in Proc. 57th Conf. Japan Management System Association National Research Presentation Competition, Sapporo University, Hokkaido, Japan, 2016,138-139 (In Japanese) 